\title{
“They'll think it's a joke, but for us, it is not!": speeches of resistance from Brazilian gay soccer clubs
}

\author{
Gustavo Henrique Carvalho de Castro ${ }^{1}$ \\ MARCUS VINICIUS SOARES SIQUEIRA ${ }^{1}$ \\ ${ }^{1}$ Universidade de Brasília (UNB) / Programa de Pós-Graduação em Administração, Brasílıa - DF, Brazil
}

\begin{abstract}
In soccer, discrimination against homosexuals is perpetrated by homophobic injury, a performative speech act that silences and excludes gay individuals, reinforcing the hegemonic masculinity. As a reaction, gay soccer clubs have emerged to provide participation in the sport. Recognizing its relevance as practices of resistance, this article analyzes discourses of resistance to heteronormativity supported by players from gay soccer clubs. Interviews were conducted with 22 gay players from these clubs present in nine Brazilian capitals. According to the interviews, interpreted from the perspective of Foucault's discourse analysis, three resistance discourses permeate such initiatives: resignification of injury by humor; interaction rules; and silences and invisibility. It is concluded that the speeches operate in a dual logic, in which the presence of statements tensioning the gender-sexuality order and the closet regime does not prevent the persistence of statements that reinforces these same heteronormative deployments.
\end{abstract}

Keywords: Resistance. Heteronormativity. Gay Soccer Clubs. Discourse.

“Vão achar que é uma piada, mas, para nós, não!": discursos de resistência em clubes brasileiros de futebol gay

\section{Resumo}

No futebol, a discriminação contra homossexuais é perpetrada pela injúria homofóbica, ato performativo de fala que silencia e afasta indivíduos gays do referido esporte, reforçando o culto à masculinidade hegemônica. Como reação, clubes de futebol gay têm emergido para proporcionar a participação dos homossexuais no esporte. Reconhecendo a relevância dessas iniciativas como práticas de resistência, neste artigo são analisados discursos de resistência à heteronormatividade sustentados por jogadores de clubes de futebol gay. Para tal, foram entrevistados 22 jogadores gays integrantes dos referidos clubes presentes em nove capitais brasileiras. Os relatos, interpretados sob a ótica da análise do discurso de Foucault, revelaram três discursos de resistência permeando tais iniciativas: ressignificação da injúria pelo humor; regras de interação; e silenciamentos e invisibilidades. Conclui-se que os discursos operam em uma lógica dual, produzindo enunciados que, embora tensionem a ordem gênero-sexualidade e o regime do armário, não impedem a persistência de enunciados que, paradoxalmente, atuam reforçando estes dispositivos heteronormativos.

Palavras-chave: Resistência. Heteronormatividade. Futebol gay. Discurso.

“Pensarán que es una broma, pero no para nosotros!”: discursos de resistencia de los clubes brasileños de fútbol gay

\section{Resumen}

En el fútbol, la discriminación contra los homosexuales es perpetrada por ofensas homofóbicas, actos de habla performativos que los silencian y alejan de dicho deportes, lo que refuerza el culto a la masculinidad hegemónica. Como reacción, han surgido clubes de fútbol gay para propiciar la participación de los homosexuales. Reconociendo la relevancia de estas iniciativas como prácticas de resistencia, este artículo analiza los discursos de resistencia a la heteronormatividad apoyados por jugadores de clubes de fútbol gay. Con este fin, se entrevistaron a 22 jugadores homosexuales de estos clubes, presentes en nueve capitales brasileñas. Los relatos, interpretados desde la perspectiva del análisis del discurso de Foucault, revelan tres discursos de resistencia que impregnan tales iniciativas: resignificación de la ofensa a través del humor; reglas de interacción; y silenciamientos e invisibilidades. Se concluye que los discursos operan en una lógica dual, en la que la presencia de declaraciones que tensionan el orden de género-sexualidad y el régimen del armario no impiden la persistencia de enunciados que, paradójicamente, refuerzan los dispositivos heteronormativos.

Palabras clave: Resistencia. Heteronormatividad. Fútbol gay. Discurso. 


\section{INTRODUCTION}

From modern Western societies to contemporaneity, homosexuality has been considered a kind of abnormality, and the homosexual, consequently, stigmatized and subordinated in the face of the ideology of masculinity (KIMMEL, 1998; HEREK, 2004; CONNELL, 2005), which values compulsory heterosexuality as a requirement for intelligibility (BUTLER, 2003). In this process, certain discourses exercise significant dominance, since they exclude and incite the exclusion of those who do not conform to expectations of normality, regulating and acting on their subjectivities (FOUCAULT, 1988).

In the soccer context, homosexuals are discriminated against by the use of homophobic insults, performative acts of speech that provide offenses to athletes and gay fans and silence them, reinforcing the cult of hegemonic masculinity (BANDEIRA and SEFFNER, 2013). In the list of these discursive practices, naturalized in competitions and virtual media, are commonplace: homophobic chants; cursing alluding to the feminization of opponents; pejorative jokes and/or double sense; and offenses directed at players, either for their performances considered insufficiently masculine or for intolerance to failures in the game (BANDEIRA, 2010; KIAN, CLAVIO, VICENT et al., 2011; ALMEIDA and SOARES, 2012; BANDEIRA and SEFFNER, 2013; MAGRATH, 2018).

And even though speeches in favor of gay inclusion in sports are manifested (KIAN, CLAVIO, VICENT et al., 2011; LUISI, LUISI and GEANA, 2016; CLELAND, MAGRATH and RIAN, 2018), the emphasis is still on tolerance, in which inclusion values expectations of conformity, such as high athletic performance, regulation of female performances and keeping sexuality a secret, from the public sphere to the very interaction with the team (ANDERSON, 2009). Thus, through homophobic discourse, systematic oppression is operated: it is a deployment that uses not only explicit means of language but also subtle means of exclusion, conforming gay athletes and fans to the closet (CAMARGO, 2018; SILVA JÚNIOR, 2018).

In reaction to the exclusions presented, gay soccer clubs have emerged as an alternative to those not in line with heteronormative precepts. These are teams composed mostly of gays seeking inclusion in soccer, as well as collective experiences of belonging to the gay community, in detriment of the frequent hostilities (JONES and MCCARTHY, 2010; STASI and EVANS, 2013; BURY, 2015; JARVIS, 2015; WILLIS, 2015). They are characterized, therefore, in the soccer context, as a form of resistance to socially imposed heteronormativity.

However, the literature concerning the phenomenon is markedly lacking and concentrated in the United Kingdom, Ireland and Iceland (JONES and MCCARTHY; 2010; STASI and EVANS, 2013; BURY, 2015; JARVIS, 2015; WILLIS, 2015), revealing the need for studies at the Brazilian context since similar initiatives have emerged on national territory, especially since 2017 (JESUS, 2019). Furthermore, the emergence of gay soccer clubs in the country is understood as a fruitful reflection for critical organizational studies, in terms of the relationship between discourse and resistance and, particularly, in sports institutions. As the discourse symbolizes a field of possibilities for forms of gay resistance (FOUCAULT, 1998), the insult itself brings the ambivalence of also being the motive of the collectivity for stigmatized and socially marginalized groups, generating many gay movements, even in sports (ERIBON, 2008).

The objective of the article was to analyze speeches of resistance to heteronormativity supported by players of Brazilian gay soccer clubs. To this end, 22 gay players participating in clubs from nine Brazilian capitals were interviewed. The data were interpreted according to the discourse analysis of Michel Foucault, which focuses on discursive devices, sexuality, and resistance.

The reflection is based on the assumption of the performativity of the statements (BUTLER, 2003), whose effects can be tensioned, as they promote slippage in established offensive discourses, either by reversing what they mean or by proceeding according to them (BUTLER, 1997; ERIBON, 2008). Thus, the research is close to queer epistemology - a post-structuralist approach whose name deliberately refers to an insult, which, resignified, is a perspective of contestation against the oppressive practices of the sex-gender-sexuality system (SOUZA, 2017). The relevance of this study lies in the critical approach to heteronormativity and in the epistemological effort to understand the practices of resistance to hegemonic masculinity (CONNELL, 2005). However, the multiform characteristic of queer studies is pointed out, whose premises are decidedly coined under the epistemological difference (MISKOLCl, 2012; SOUZA, 2017). 
In the context of critical organizational studies, the article highlights the growing interest of the field in the reflections coming from queer studies (SOUZA, 2017). The contribution lies in understanding that gay soccer clubs, as sports organizations, operate according to the logic of organizing, whose organizational units are not stable - existing a priori or pre-discursive but continuous processes markedly political-discursive (SOUZA, COSTA and PEREIRA, 2015).

\section{HETERONORMATIVITY AND RESISTANCE IN SPORTS}

Homophobia can be viewed in cognitive, affective, and behavioral terms (HEREK, 2004; BORRILLO, 2010; PIEDRA, 2015). In the cognitive aspect, "[...] the object of rejection is not homosexuality as an individual, but homosexuality as a psychological, and social phenomenon" (BORRILLO, 2010, p. 22). In the affective aspect, there is an allusion to the "rejection of homosexuals" (BORRILLO, 2010, p. 22), manifested by feelings of rejection. The behavioral aspect is exemplified in the interactions in sports competitions, such as hate externalizations, verbal and/or physical aggression, as well as veiled discriminations, such as the daily ostracism in relation to gays (PIEDRA, 2015).

In the universe of hegemonic masculinity, the narrative "to be a heterosexual man" imposes itself as the only possibility of masculinity (CONNELL, 2005), uncovering homophobia as a mix of sexism and machismo. For men, not being masculine enough is the logical primacy of the association between homophobia and the heteronormative pattern of masculinity: fear of being feminine, of not meeting cultural expectations, of being gay (KIMMEL, 1998). Homophobia is inscribed in a social order of gender-sexuality, whose structuring dualism homo-heterosexuality (SEDGWICK, 1993) operates as a perpetuating deployment of compulsory heterosexuality (BUTLER, 2003).

Heteronormativity, therefore, is what best represents the effects of sexuality deployment (FOUCAULT, 1988), articulating the said and unsaid and imposing production and intelligibility schemes on individuals (MISKOLCl, 2012). It "[...] describes the tendency of the contemporary Western sex-gender system to view heterosexual relations as the norm, and all other forms of sexual behavior as deviations from that norm" (SPARGO, 2017, p. 53). However, the conceptual line between homophobia and heteronormativity is tenuous, since both are articulated around collective beliefs, acts, and representations (BORRILLO, 2010). Therefore, didactically, homophobia is distinguished as discrimination (reflection) and heteronormativity as a deployment (producer of intelligibility) (MISKOLCl, 2012).

Heteronormativity is something that fits early in sports relationships. Male socialization in sports begins in the contexts of physical education, where many boys, in the process of "becoming men", assimilate gender codes and recur to pejorative terms among themselves (LOURO, 2003; ANDERSON, 2009; BANDEIRA, 2010), promulgating, through repetition, the accepted gender performances (BUTLER, 2003). Therefore, to be effeminate, for example, is to transgress expectations, because any allusion to homosexuality is threatening, regardless of whether the individual is gay (KIMMEL, 1998; BORRILLO, 2010).

In these contexts, homosexuals are associated with non-male performance. It is through homophobic insult that stigmas about the gay are reinforced in the language (ERIBON, 2008). Such insult is an act (or series of acts) of speech, constitutive of the homosexual experience and which imposes on the gay the outrage of his subjectivity, producing as a consequence the internalization of homophobia (HEREK, 2004). In other words, these are insults that inaugurate discursively relationships of domination to which homosexuals are subordinated, including even less explicit means, such as "[...] gossip, allusion, insinuation, evil words, [...] rumor, [...] more or less explicit, more or less poisonous play" (ERIBON, 2008, p. 64). It is the affective-cognitive injunction of homophobia in language (BORRILLO, 2010). Through the insult, in childhood, we learn about our own sexuality and that of others (MISKOLCI, 2012).

In soccer - a sport notably masculine in most countries and of wide popularity (OLIVEN and DAMO, 2001) -, homophobic insult is naturalized under the mantle of language shared by fans. For many of them, pronouncing homophobic insults is considered harmless, an authentic way for collective expression (BANDEIRA, 2010; CLELAND, 2018). In this context, the insult proliferates with the leniency of coaches, clubs, and federations, among other institutions related to soccer, and homophobia is confused with the interactional rite itself, marking the game and being understood as male socialization in stadiums and other spaces (ALMEIDA and SOARES, 2012; CASHMORE and CLELAND, 2012; MAGRATH, 2018). 
In face of this, male homosociality (SEDGWICK, 1985) emerges in group athletic modalities as a social bond established in the paradox of repressing homoerotic desires, constantly projecting homosexuality in speeches, chants, jokes, obscenities, and swearing (ERIBON, 2008; CAUDWELL, 2011). The insult and homosociality corroborate the heteronormative deployment because they advocate that the symbol of masculinity is to be someone masculine, competitive, aggressive, virile, and, above all, heterosexual (BANDEIRA and SEFFNER, 2013). Also, as a deployment, they have pedagogical action (LOURO, 2003), since they allow disciplining codes that state who is fit for the game and the crowd, and who is not (BANDEIRA, 2010; BANDEIRA and SEFFNER, 2013).

Homosexuals, under the constant threat of individual depreciation, hardly remain in this type of regime (ERIBON, 2008; ALMEIDA and SOARES, 2012). Therefore, to participate in soccer, schemes are adopted: as fans, they use tactics to frequent the stadiums, such as silencing themselves in the face of homophobic attacks or otherwise uttering the same insults against others, mimicking heterosexual behaviors (SILVA JÚNIOR, 2018); as non assumed players, hiding sexual orientation, secrete private life in the simulacrum of heterosexuality (ANDERSON, 2009); and, of the few who "come out of the closet", this occurs only happens after they finish their soccer career (CLELAND, MAGRATH and RIAN, 2018). In the case of famous soccer players, for example, the coming-out, besides condemning them to isolation, ostracism, and the renegation of their own identity, bumps into the fear of sports organizations having their images jeopardized (KIAN, CLAVIO, VICENT et al., 2011; CLELAND, 2018; LUISI, LUISI and GEANA, 2016).

In this way, the contours of the closet are outlined in soccer, where it is even possible to be gay, if one does not talk about it (SEDGWICK, 1993). In sports, this philosophy of secrecy is known as "don't ask, don't tell" (CAMARGO, 2018) - a mantra originated in military institutions in their policy of secrecy on homo and bisexual practices (BUTLER, 1997). According to Eribon (2008), sport is the place of open homosexual identity unfeasible, because gay athletes and fans are led to understand sexuality as unquestionable, even though heterosexuality itself constitutes compulsory, overflowing in different discursive enunciations (ANDERSON, 2002; ERIBON, 2008).

Moreover, even though that literature significantly accumulates discourses from other actors in favor of gay acceptance in the soccer universe (ANDERSON, 2002, 2005, 2009; KIAN, CLAVIO, VICENT et al., 2011; PEREIRA, ALFAIA, SOUZA et al., 2014), the emphasis in these discourses - accessed mostly in media and forums - is on expressive tolerance to homosexuals, instead of their full inclusion (CAMARGO, 2018). This reinforces the heteronormative deployment in the face of expectations such: high athletic skills of assumed gay men; regulation of female performances; and maintenance of sexuality in the domain of secrecy, from the public sphere to interactions with the team (ANDERSON, 2009). Thus, the problem that arises is that in such researches, besides capturing the heterosexual view, instead of collating reports of gay sportsmen, it ends up reifying the homosexual as a deviant.

It is considered that homophobic discrimination in sport is something systematic, which starts from multiple means of the exercise of the heteronormative deployment, evidenced in the reinforcement of the gender-sexuality pair and induction to the closet (SEDGWICK, 1993; BUTLER; 2003). However, for each form of oppression, there is the possibility of resistance (FOUCAULT, 1988, 1998); therefore, the idea of specifically gay soccer may suggest discourses and practices that represent agency points for homosexual players.

If the collective declaration of homosexuality is reflected as a possibility of tensioning the closet regime in sports and the sex-gender order, then resistance to the sexuality deployment is practiced (FOUCAULT, 1988). In this sense, deployment is not equivalent to power, as conventionally thought in macropolitical dynamics (FOUCAULT, 1998), but to the unstable grid of micro-practices, which combines said and unspoken and predestines itself to be a truth about sex, interdicting certain forms of existence in public life and producing subjectivities (SOUZA, COSTA and LOPES, 2019). Homosexuality is a case of the production of marginal bodies by such a deployment. In such a thinking system, sexual repression is also contested, since control is imposed in the form of successive discursive outbreaks on sexuality in multiple knowledges (FOUCAULT, 1988), and soccer would be one of them (BANDEIRA, 2010).

Thus, resistance is an act of transposition of the conditions of subjection in persistent attempts to escape the serialization of subjectivities, emancipating subjects as individuals (SOUZA, COSTA and LOPES, 2019). Because there is social capillarity of power, resistance is never at the extreme of exteriority about it, since power punishes exactly because it is a measure of combat to resistance (FOUCAULT, 1998). 
In this correlation of forces, discourses on gender-sexuality in soccer are performative, in the sense that they (re)cite socially agreed-upon gender and sexuality behaviors (BUTLER, 2003); some of them have dominance status, controlling and distributing statements according to procedures that ensure the events (FOUCAULT, 1999). Therefore, resistance may be in (counter) discourse, which aims to reverse power, manifesting itself as a resignification of discourse and, therefore, of power, while still "[...] being the same discourse, which proceeds according to the same categories, but which reverses or transforms what they mean" (ERIBON, 2008, p. 378).

Considering that gay soccer clubs have been spreading in the international arena, it should be reinforced that the theoreticalempirical record is scarce. In the United Kingdom, for example, the non-performativity (ineffectiveness) of speeches on plans to combat homophobia in soccer was critically investigated by strengthening gay soccer clubs and leagues, in addition to hegemonic representations of the male and the gradual inclusion of heterosexual athletes in these clubs (JONES and MCCARTHY, 2010; BURY, 2015; JARVIS, 2015). In the Irish context, it was researched how gay players inserted in gay clubs and leagues promote disruptive practices, while they also reinforce certain gender and sexuality norms (WILLIS, 2015). In Iceland, in turn, the incorporation of gender in the speeches of gay players has been observed (STASI and EVANS, 2013). Finally, the literature encourages analysis of other gay formations in soccer around the globe, corresponding to the present work of reflection on the discourse of resistance to heteronormativity in gay soccer in Brazil.

\section{METHODOLOGICAL PROCEDURE}

This research was developed with the participation of players from Brazilian amateur gay soccer clubs, most of whom were part of the National Gay Soccer League (LGNF) in 2019. Briefly characterized, LGNF, henceforth LiGay, is a federation created in 2017 to disseminate events associated with gay soccer in the country. Since then, it organizes a six-monthly edition of Champions Ligay, a championship whose brand is to be a parody of the European Champions League ${ }^{\circledR}$, joining a party and soccer (JESUS, 2019).

The fourth edition of the event was held in Brasilia in the first semester of 2019, with 24 teams, one locale, and the others coming from various Brazilian capitals. In the context of this event, 17 gay players from eight teams from the cities of Manaus, Goiânia, Belo Horizonte, Vitória, São Paulo, Rio de Janeiro, Porto Alegre, and Curitiba were selected for convenience and interviewed in two days. Later, through the snowball sampling technique, five more players from two gay soccer clubs in the Federal District were interviewed, one of them not federated to LGNF. The total number of players interviewed was 22 .

For the conduction of the interviews, a semi-structured script was adopted, supported both by prior approval by a research ethics committee and by written authorization from each participant, both to be a volunteer and for the transcription of the audio of the interview for the purpose of the research. The script adopted made it possible to apprehend players' visions and experiences about homophobia and heteronormativity in soccer and life in society, as well as about the practices of resistance exercised in gay soccer.

Regarding the profile of the interviewees, they all declared themselves gay; the largest portion comes from teams located in Brasília, Rio de Janeiro, and São Paulo; has higher education, being recurrent occupations as a physical educator, public servant, and journalist; and average age approximately 29 years. Each interlocutor is identified in the excerpts by a code that goes from J1 to J22, so as not to jeopardize the confidentiality of their identities.

A first general observation of the interview reports allowed to gather the most recurrent and significant statements for the objective of the work, which were organized within a textual corpus. For Foucault (2008), besides repetition as a principle to recognize the enunciation as such, it is necessary not to restrict it to the acts of speech, phrase, or proposition, even because it is a set of signs that, already preceded by a network of discourses and knowledge, allows, even by randomness, reaffirming certain discursive formations. These are identified if it is possible "[...] to show how they all derive (despite their sometimes-extreme diversity, despite their dispersion in time) from the same set of relationships" (FOUCAULT, 2008, p. 76). Thus, it can be inferred that, while statement and discursive formation are intrinsically related, discourse is, in the Foucauldian domain, a said that rests on another precedent (FOUCAULT, 2008). 
Thus, the analysis carried out resorted to the external dimensions of discourse delineation, which, although not consisting, in a broad sense, of theoretical categories, made it possible to grasp the rules that "[...] are exercised in a certain way from the outside; they function as systems of exclusion; they concern, undoubtedly, the part of the discourse that puts power and desire at stake" (FOUCAULT, 1999, p. 21), that is:

- Prohibition of the word (under what circumstances is the discourse on sexuality forbidden? Who can and who cannot speak? What cannot be said?);

- Separation and rejection (what are the silences behind the separation and rejection of speeches? What is censored? What discourse is considered null or irrational?);

- Will to knowledge (what practices of knowledge engender the truth about the object in question? Which institutions are in charge of disseminating knowledge on the object studied?).

Besides, the present critique is based on Foucauldian reflections on the deployment of sexuality and resistance (FOUCAULT, 1988, 1998), aligning itself with the intellectual enterprise of genealogical critique (FOUCAULT, 1999), in which, besides the notion of discursive formation, discourses, such as that of sexuality, come to be understood as situated in the field of power relations.

As a queer analysis, we try to apprehend the sex-gender order and the closet regime, as well as the tensioning (or reinforcement) of these deployments in statements about: intelligibility, insult, citationality, gender-sex performativity, interpellation, hegemonic masculinity, and homosociality, among other concepts once approached.

\section{RESULTS AND DISCUSSIONS}

For Foucault (1998), individuals become, continuously, subject through processes of subjectivation. In the sports scene, hegemonic masculinity can be considered as subjection, legitimating the reproduction of higher values for the masculine and heterosexual and depreciative schemes on homosexuality (ANDERSON, 2005; CONNELL, 2005).

In (J4), indications are suggested on how conventional soccer engenders certain mechanisms of subjection:

Look, I've been playing soccer since I first understood myself as a person. So, I always played soccer, but I can never be myself, right? The [mentions his name], which is gay, can never come out. So always in the games, I heard talk of women and such and I could never come and talk about a boyfriend or some situation within the gay environment, which is my environment, right? So, I was not myself (J4).

The discourse on the experience of becoming a soccer player, for gay athletes, goes through the prohibition (FOUCAULT, 1999) of the homosexuality attribute (FOUCAULT, 1988), which, in the case of (J4) implies the renunciation of a central marker of life, corresponding to stop being himself in games, places, by excellence, of the masculine hegemony (BANDEIRA and SEFFNER, 2013).

According to Louro (2003, p. 75), in societies like the Brazilian one, "[...] liking soccer is considered almost an 'obligation' for any 'normal' boy". Thus, the gay man is understood as someone subjectivized in soccer by the impossibility of living the experience of his sexual orientation, in a free and uncompromising way with judgments, which interferes in the very conception of the individual's agency - exercise of desire, in counterpoint to the imposed order (MISKOLCI, 2012). The statement is representative of the sports closet (CAMARGO, 2018), in which even the coming-out is something not univocal, so that the individual, at various times, goes back to the closet (SEDGWICK, 1993).

(J8) metaphorically portrays this process: “[...] we stay inside a cocoon because you can't... first because you can't demonstrate that you're gay, right? So you have, even if veiled, a lot of rules like that, like...you have to go out with a woman, you have to... you can't have certain kinds of behavior inside that environment" (J8). Thus, to maintain a legitimate identity before peers, in the context of soccer, is to undertake tactics that, to the extent that they protect, meet heteronormative aspirations. It should be noted that many gay supporters use imitation as a form of protection among supporters organized in Brazilian stadiums 
(SILVA JUNIOR, 2018). It is the performativity of gender in action, the ability existing in the statements to indicate the signs that cite (and incite) the masculine-heterosexual: "dating women", "not having certain behaviors"...; an alignment that not only reflects heterosexual expectations but reiterates them in an almost compulsory manner (BUTLER, 2003).

Regarding the discrimination experienced in sports institutions by those who had previously played in "straight" teams (as many of those interviewed referred to conventional teams), (J15) reflected on how their sexual orientation was rejected: "[they] avoided, avoided contact, but normal, right? He is leading a normal life. But they were surprised, right? Not because of the idea of not knowing that I was homosexual, but that I liked the sport [laughs]" (J15). The statement carries the assumption that homosexuality and soccer would be antagonistic. In Brazil, the sport forges productive male bodies even in leisure (MISKOLCl, 2013), so that the homosexual body is seen as unproductive and therefore excluded from the sport (J18) corroborates: "[...] society sees a guy playing ball, he's a man, right? [...] You're not going to find one there - sorry about the word here - a 'fag" (J18).

Therefore, relationships among men themselves are controlled and objects of knowledge, pedagogies, and discursive formations (FOUCAULT, 1988), orders before which interlocutors become targets for interpellation (BUTLER, 2003). Prejudice in sports has markers of veiled discrimination, which does not qualify as verbal aggression, nor carries the mask of good humor (PIEDRA, 2015). It is the prejudice inscribed in the silence, in the absence of speech, but not dissociated from the discourse (FOUCAULT, 1999).

The statements corroborate the silence of sports institutions: "locker room culture" (CAMARGO, 2018). It is the discursive interdiction, which gains its contours in the daily exclusions and acceptance of stigma, perpetrated by agencies and clubs, media and press, fans (KIAN, CLAVIO, VICENT et al., 2011; CASHMORE and CLELAND, 2012; CLELAND, 2018; MAGRATH, 2018) and even by legally established systems (ALMEIDA and SOARES, 2012; BANDEIRA and SEFFNER, 2013).

Thus, if silence is a discursive strategy that admits certain discourses, at the expense of the exclusion of others, and if what poses a risk to male homosociality is not the erotic act itself, but the talk about being gay, how can we characterize the discursive practices of resistance sustained by Brazilian gay soccer clubs around hegemonic masculinity, which rules as a discursive order of gender and sexuality? Based on the interpretation of the reports, we present and discuss, in subsections, three identified speeches of resistance.

\section{Resignification of the insult by humor}

According to Foucault (1999), a discourse has no meaning forever defined, so it acts according to the strategic functions it occupies. Therefore, gay soccer players are seen as provisional, citing gender and sexuality rules, within a matrix that communicates to which individuals intelligibility is conferred.

International research on gay soccer has indicated that the experience of being part of specifically gay clubs provides inclusion by promoting collective practices that encourage the spirit of genuine soccer and avoid excesses of hostility and aggression (JONES and MCCARTHY, 2010; STASI and EVANS, 2013; WILLIS, 2015). About "LGBT sports", Camargo and Rial (2011), in experiences in these competitions, indicated that irony is a figure of language frequently employed by actors. Expressions of call in the feminine, for example, are part of the rite of interaction between gay sportsmen, which had already been understood even in studies about gay collectivities (ERIBON, 2008).

This humorous speech was taken to the ambit of the queer supporters in Brazil, who erupted in 2013 as manifestations of resistance, especially in the virtual context and in some stadiums, bringing together claims of respect for assumedly gay fans (BANDEIRA and SEFFNER, 2013). Thus, the irony is a figure of speech observed also in the teams investigated, viewed in statements that include, to contest heteronormativity, the archetypal animal-humor-erotism, notably in names such as, for example, "Alligaytors", "BallCats", "BeesCats SoccerBoys" and "Predators".

The humorous brand of gay soccer has its genealogy in the very nomenclature that teams adopt (JESUS, 2019). Most of them suggest, for example, affront, bravery, and diversity as principles of gay resistance, but also eroticism and irony (J10) indicates that humor and joking are means of affirming one's sexual orientation, and states: "Ah, it's an affirmation! It is an affirmation. Okay, you call me a fag? I am a faggot! What are you going to do? [tone of laughter]. Are you going to exclude me? [laughs]" 
(J10). Or, as puts (J20), "Look, do you want to call us 'faggot'? We really are. We are much more". Meanwhile (J12) stresses the symbolism behind the names of the clubs, giving it a meaning of survival: "It's a mark of survival. It's a way to stay alive, present. We can't go in the force? we go in the humor. [...] To show that we resist through grace" (J12). Thus, words like "affirmation" and "survival", taken from the explanations themselves, suggest the emergence of forms of (re)organization of subjectivity in these movements (SOUZA, COSTA and PEREIRA, 2015).

I think it's in the nature of the gay he is more folkloric, he likes to dance... [...] He is more expansive by nature. I think that brings happiness. So, when we get here... everybody has a hard week, we work hard. It's a moment of leisure, so, "BLUFT!" It blows up. You explode glitter for everything that is side by side, because here is the time to extravasate. [...] When you score a decisive goal in straight soccer, you kind of provoke a confrontation. In gay, when he makes some move that he kills a lot, he imitates Beyonce, he gives some screams, normal middle gay like this [...]. I mean, in a straight soccer, it would be inadmissible for a guy to score a goal and go out wiggling, celebrating. It looks like a huge mockery (J19).

(J19) suggests the insertion of humor in the matches at moments of greater vibration of the team, indicating series of resistances that use not only the resignification of insults, but also bodily acts (BUTLER, 2003), suggesting irreverence. Happiness is an element of the discursive elaboration about what it is to be gay, which allows you to adopt dissonant body practices of the heteronormative (CAMARGO, 2016), such as "dancing", "imitating Beyonce" and "going out wiggling, celebrating"; while it also erupts with the discursive order, operating new discursive practices, either by giving "a few shouts", or making "jokes" of the "gay environment", or even resignifying the homophobic insult itself suffered.

In this sense, by the appropriation of depreciative words, the insult itself is resignified (BUTLER, 1997; ERIBON, 2008), and this is reflected intensively in the teams researched. As points out (J7), "[...] in the first moment is a matter even to draw attention and show that we do not need to put the heteronormative name in the name of the team to be a soccer team. It is to show that really using a team that other people, the straight ones, or other people, they'll think is a joke, but for us, it is not! It's a reason to be proud" (J7). Thus, visibility is promoted with a message that has the purpose of "attracting attention", because, although initially appeared to be a joke (or insult), it is a means of transmitting pride and feeling of collectivity to the participants.

This statement is in line with what another player categorically scored: "it's affirmation" (J10). It follows that "putting the name heteronormative" in these circumstances is to weaken the discursive strategy of resistance employed. In other words, "[...] one should not imagine a world of discourse divided between admitted and excluded discourse, or between dominant and dominated discourse; [...] a multiplicity of discursive elements that can enter into different strategies" (FOUCAULT, 1988, p. 94). Nor do reverse discourses necessarily lead to another discourse because they can refer to that same discourse, which now, proceeding according to the same categories, reverses the first discourse or transforms what these categories mean (BUTLER, 1997; ERIBON, 2008).

\section{Rules for interaction}

Another discourse is the rules of the gay soccer game. One of them is related to the offenses and behaviors themselves that involve pejorative expressions (J12), when asked about how change occurs through discursive resignification, presents it when dealing with gay soccer: "Of course, among friends, one calls the other gay, a faggot, a faggot. They are jokes. We know the tone. But it's not allowed; in fact, it's forbidden, offenses, homophobia, or any other kind of aggression. Athletes like this, teams that come with this conscience, are filtered and, if they don't fit in, are excluded" (J12).

This statement is an effective mechanism for regulating insult, because, depending on the connotation it carries, it can go back to the very problem that originates it: the homophobic prejudice. This inference finds support in "we know the tone": it is a way of recovering the inflexion zone that gives rise to the homophobic insult. Such a mechanism implies filtering that, in disrespectful circumstances, can even lead to the exclusion of teams from the league (J9) recognizes that the tactic is part of a contract: "[...] we cannot speak in an aggressive way to another colleague. In fact, it is a team contract when we take part in Ligay. So, there are some rules, in which we can't offend, we can't do some things..." (J9). 
The attempt to prevent aggression and disrespect in gay soccer, compared to conventional soccer, is observed, considering that not all clubs will have the same levels of awareness, as had been recognized by (J12). In this sense, it is possible to point out that not even gay soccer is safe from the prejudice of other institutions and, therefore, from the society. Even other rules are dispensed with, such as more timely attitudes towards the attempts of heterosexuals to participate in clubs, which would characterize the subversion of the affirmation that sustains itself and would lead to the idea that "everyone is equal", a narrative that would certainly damage the visibility and affirmation of gay soccer.

Once a friend of mine turned to me and said: "Yeah, but how is it inclusive soccer if you only accept the gay?" I agree, but at first, we need to show that the gay has space in soccer [...] But I believe that in about ten years it will be over. And the gay man will play with the straight man, the straight man will be playing here with us and he won't have this one anymore: "Ah, the team is gay". It is a soccer team that has gays and has straights playing and everybody respecting each other (J4).

The statement of (J4) highlights the issue of inclusion and how resistance to the participation of a heterosexual player in gay soccer teams can be equivalent to not accepting gays in straight teams (J4) attests to optimism regarding the full inclusion of homosexuals in the sport, which, although not significant in contemporaneity, may, in a short time, reach higher levels. By characterizing the current situation of gay clubs as something temporary, the interlocutor understands that organizing in specific gay teams is a momentary strategy to deal with the prejudice rooted in society. However, it is forgotten that the stigmatization of homosexuals, not only in sports, is part of a pedagogy and is inserted in a historical deployment that prohibits certain characters, ensuring the immutability of the scheme (FOUCAULT, 1988; LOURO, 2003). Meanwhile (J19) is more emphatic in his assertion, giving high resistance to the insertion of other non-gay subjects: "This is our place of speech, our point of resistance. The girls, they already have a lot of soccer out there. The straight ones? Gosh, there's plenty of them. Look around here! What else is 'the straight soccer'. So, you can come and play, but you're not part of the group, you're just a guest that we like".

In this aspect, heterosexuals, when they reprimand these sports associations for claiming separatism, carry a discourse that the sport should be neither homosexual nor heterosexual, forgetting "[...] that it is deeply heterosexual and that a gay man who declared himself as such would have great difficulty in continuing to be admitted to a team" (ERIBON, 2008, p. 145).

It is clear from this class of statements that, although language represents one of the main strategies of resistance, it has not failed to be guided by the imposition of rules both endogenously and exogenously, to emphasize coherence about the narrative that gay soccer sustains.

\section{Silences and invisibilities}

According to Foucault (1988), repression does not take place only through coercion. Rather, it uses a thought of injunction to silence and affirmation of non-existence, in which "[...] it is really necessary to give way to illegitimate sexualities, which are going to bother elsewhere: which bother there where they can be reinstated, if not in the circuits of production, at least in those of profit" (FOUCAULT, 1988, p. 9).

(J20) believes that, in relations with "straight" soccer teams, there is no room for prejudice, although presents this in a controversial way:

There is a club that already looks like this: "we can't lose to the gays". And when they start to lose, they begin to make a lot of foul, because I think they can feel inferior. [...] There's a team that doesn't give a damn. He is not going to play football against a gay team or a straight team. He is going to play ball against a team! [...] And other teams say: "Ah, it's the gay team, we won't miss this one, otherwise we'll be the team that lost to the gay team" (J20).

What is stated is that it is necessary, even in this context, to prove high sports performance. In other words, it may be gay, but it is also necessary to "play well". From the speech of (J20), it is possible to highlight two attitudes coming from conventional teams about gay soccer teams. The first is a game-centered relationship, in which the sexuality of the opponents would not matter. The second attitude contradicts the first, when it communicates that playing against a gay team and suffering a defeat is what denotes a weak team, since the expectation that the gay would not know how to play soccer well is in force (ANDERSON, 2005). There is resistance from other "straight" teams when it is known that the confrontation will be with a gay team. 
In this aspect, homosexuality itself is regulated in gay sports. Homosexual tolerance is reified by agents who, although they accept it, do it in accordance with hegemonic masculinity (ANDERSON, 2002). It is important to remember that gay-friendly discourse is characterized by valuing only the athletic capacity of the subjects in the sport. Although acceptance speeches in favor of gays are growing, a hegemonic part still has difficulty in dealing with information (PEREIRA, ALFAIA, SOUZA et al., 2014).

It was also observed that some gay teams have operated almost in invisibility. Although teams represent authentic resistance in gay soccer, some are not even seen as gay teams (J18) admits that the team plays well, but still has "difficulties to position itself as a gay team". Among other teams, which still do not communicate their own identity as a gay team, what persists is the opposition to the discursive order of silence. Thus, to apprehend it as a gay team, it would be necessary to either ask or infer from unconventional performances, and misaligned with performativity, demanded by society (BUTLER, 2003), about who would or would not be gay, and, by extension, understand the team as a gay stronghold (ALMEIDA and SOARES, 2012; BANDEIRA and SEFFNER, 2013).

Thus, it is understood that prejudice is still an obstacle for those who participate in gay clubs. The statements suggest that, although visibility is important, the own brand of gay sexual orientation may not come to the fore in the interactions of gay soccer teams with their surroundings. For Foucault $(1988$, p. 95), "[...] it is necessary to admit a complex and unstable game in which speech can be both an instrument and a power effect [...] point of resistance and starting point of an opposite strategy".

As Foucault (1988) also expounded, the discourse has as an integral part of the silences as a strategy. In this peculiar dynamic of resistance, while the heteronormative discourse takes over even the very cause that gay clubs bring to the sport; in another measure, the gay silencing within the sports institutions themselves is in force and remains unquestioned (J22) ponders:

[...] the soccer industry, it doesn't have such good eyes for homosexuality. So I'm hopeful that professional and amateur players can express their sexuality freely [...], maybe in about 10 years, we can see two... see two, I don't know...kissing...professionals, in their lives, personal, and everybody is 'shitting and walking for it' (J22).

The statement once again expresses optimism about gay inclusion in soccer, of becoming natural to the point of no segregationism. Moreover, by mentioning soccer as an industry, the enunciation allows to recover the supremacy of the homophobic language in sports, where many high-performance athletes remain in the closet to be successful. It can be inferred that there is an awareness of the passing situation of forming gay teams and the barriers culturally imposed to be overcome.

\section{FINAL REMARKS}

It is concluded that the discourses adopted operate in a dual logic, in which the presence of enunciations tensioning the gender-sexual order and the closet regime does not prevent the persistence of enunciations that act reinforcing these heteronormative deployments. The results suggest that, despite the use of different discursive strategies, such as humor, to mitigate homophobic insult, the discourse that it is important, above all, to know how to play soccer suggests silencing and invisibilization of gay soccer clubs. The analysis made it possible to understand that, although gay soccer in Brazil differs in several elements from conventional soccer, especially in the clamor for inclusion and the fight against homophobia, it experiences obstacles to position itself as an authentic front of resistance to hegemonic soccer, facing difficulty in interfering with the dynamics of sports organization itself.

Moreover, even in gay soccer, which spreads resistance, at the same time discursive practices have been selected and subverted or reiterated, referring in gay to an ideology of hegemonic masculinity in soccer. It is argued that the discourse was built on a contra discourse. In other words, the discursive strategies used allowed the creation of gay soccer as a system of resistance that could include gays in the sport and decrease the influence of heteronormativity. 
Given the above, future studies are necessary, dedicated to the understanding of gay soccer, also capturing the facet of the conversation on the field, analyzing the interactions in the course of the verbal interaction itself between the players, fans and other fans of the sports practices addressed. The use of discursive ethnography is encouraged as an alternative to apprehend the taking of the discourse in action in the locus of the activity itself.

This study contributes to the field of critical organizational studies, highlighting political organizing practices in institutional contexts permeated by discursive practices that are, at the same time, evidence of power and agency-resistance. Finally, the study encourages, within the scope of critical organizational studies, analyses based on resistance as an organizational phenomenon, taking as relevant the discursive facet in the world of soccer.

\section{ACKNOWLEDGEMENTS}

This work was carried out with the support of the Coordination for the Improvement of Higher-Level Personnel - Brazil (CAPES) - Financing Code 001. 


\section{REFERENCES}

ALMEIDA, M. B.; SOARES, A. O futebol no banco dos réus: caso da homofobia. Movimento, v. 18, n. 1, p. 301-321, 2012.

ANDERSON, E. In the game: gay athletes and the cult of masculinity. New York: State University of New York Press, 2005.

ANDERSON, E. (2009). Inclusive masculinity: the changing nature of masculinities. Londres: Routledge.

ANDERSON, E. Openly gay athletes: contesting hegemonic masculinity in a homophobic environment. Gender \& Society, v. 16, n. 6 , p. 860-877, 2002.

BANDEIRA, G. A. Um currículo de masculinidades nos estádios de futebol. Revista Brasileira de Educação, v. 15, n. 44, p. 342-410, 2010.

BANDEIRA, G. A.; SEFFNER, F. Futebol, gênero, masculinidade e homofobia: um jogo dentro do jogo. Espaço Plural, v. 14, n. 29, p. 246-270, 2013.

BORRILLO, D. Homofobia: história e crítica de um preconceito. Belo Horizonte: Autêntica, 2010.

BURY, J. Non-performing inclusion: a critique of the English Football Association's Action Plan on homophobia in football. International Review for the Sociology of Sport, v. 50, n. 2, p. 211-226, 2015.

BUTLER, J. Excitable Speech: a politics of the performative. New York: Routledge, 1997.

BUTLER, J. Problemas de gênero: feminismo e subversão da identidade. Rio de Janeiro: Civilização Brasileira, 2003.

CAMARGO, W. X. Dilemas insurgentes no esporte: as práticas esportivas dissonantes. Movimento, v. 22, n. 4, p. 1337-1350, 2016.

CAMARGO, W. X. O armário da sexualidade no mundo esportivo. Estudos Feministas, v. 26, n. 1, p. 1-18, 2018

CAMARGO, W. X.; RIAL, C. S. M. Competições esportivas mundiais LGBT: guetos sexualizados em escala global? Estudos Feministas, v. 19, n. 3, p. $977-1004,2011$

CASHMORE, E.; CLELAND, J. Fans, homophobia and masculinities in association football: evidence of a more inclusive environment. The British Journal of Sociology, v. 63, n. 2, p. 370-387, 2012.

CAUDWELL, J. 'Does your boyfriend know you're here?' The spatiality of homophobia in men's football culture in the UK. Leisure Studies, v. 30, n. 2, p. 123-138, 2011.

CLELAND, J. Sexuality, masculinity and homophobia in association football: an empirical overview of a changing cultural context. International Review for the Sociology of Sport, v. 53, n. 4, p. 411423, 2018

CLELAND, J.; MAGRATH, R.; KIAN, E. The internet as a site of decreasing cultural homophobia in association football: an online response by fans to the coming out of Thomas Hitzlsperger. Men and Masculinities, v. 21, n. 1, p. 91-111, 2018.

CONNELL, R. W. Masculinities. 2a. ed. Berkeley: University of California Press, 2005.

ERIBON, D. Reflexões sobre a questão gay. Rio de Janeiro: Companhia de Freud, 2008.
FOUCAULT, M. A arqueologia do saber. 7. ed. Rio de Janeiro: Forense Universitária, 2008

FOUCAULT, M. A ordem do discurso. 5. ed. São Paulo: Edições Loyola, 1999.

FOUCAULT, M. História da sexualidade I: a vontade de saber. 13 ed. Rio de Janeiro: Edições Graal, 1988.

FOUCAULT, M. Microfísica do poder. 13. ed. Rio de Janeiro: Edições Graal, 1998.

HEREK, G. M. Beyond "homophobia": thinking about sexual prejudice and stigma in the twenty-first century. Sexuality Research \& Social Policy, v. 1, n. 2, p. 6-24, 2004

JARVIS, N. The inclusive masculinities of heterosexual men within UK gay sport clubs. International Review for the Sociology of Sport, v. 50, n. 3, p. 283-300, 2015.

JESUS, D. S. V. "Futebol é coisa para mano, mana e mona?" A LiGay nacional de futebol society do Brasil. Periódicus, v. 1, n. 10, p. 343372,2019

JONES, L.; MCCARTHY, M. Mapping the landscape of gay men's football. Leisure Studies, v. 29, n. 2, p. 161-173, 2010.

KIAN, M. et al. Homophobic and sexist yet uncontested: examining football fan postings on internet message boards. Journal of Homosexuality, v. 58, n. 5, p. 680-699, 2011.

KIMMEL, M. S. A produção simultânea de masculinidades hegemônicas e subalternas. Horizontes Antropológicos, v. 4, n. 9 , p. 103-117, 1998

LOURO, G. L. Gênero, sexualidade e educação: uma perspectiva pósestruturalista. 6. ed. Petrópolis: Vozes, 2003.

LUISI, M. L. R.; LUISI, T.; GEANA, M. V. Homosexuality and the heartbeat of a locker room: an analysis of quotations in the context of hegemonic and inclusive masculinity theories. Journal of Homosexuality, v. 63, n. 10, p. 1314-1338, 206.

MAGRATH, R. 'To try and gain an advantage for my team': Homophobic and homosexually themed chanting among English football fans. Sociology, v. 52, n. 4, p. 709-726, 2018.

MISKOLCl, R. O desejo da nação: masculinidade e branquitude no Brasil de fins do XIX. São Paulo: Annablume, 2013.

MISKOLCI, R. Teoria queer: um aprendizado pelas diferenças. Belo Horizonte: Autêntica, 2012.

OLIVEN, R. G.; DAMO, A. S. Fútbol y cultura. Buenos Aires: Editorial Norma, 2001

PEREIRA, A. S. et al. Preconceito contra homossexuais no contexto do futebol. Psicologia \& Sociedade, v. 26, n. 3, p. 737-745, 2014

PIEDRA, J. Gays y lesbianas en el deporte: discurso de jóvenes universitarios españoles en torno a su aceptación. Movimento, v. 21 , n. 4 , p. 1067-1081, 2015

SEDGWICK, E. K. Between men: english literature and male homosocial desire. New York: Columbia University Press, 1985. 
SEDGWICK, E. K. Epistemology of closet. In ABELOVE, H.; BARALE, M. A.; HALPERIN, D. M. (Eds.). The Lesbian and Gay Studies Reader. New York: Routledge, 1993. p. 45-61.

SILVA JÚNIOR, J. A. Pedagogia do armário: identidade, pertencimento e apropriação do futebol por torcedores homossexuais. 2018. 160f. doctors I Dissertation (Doctor Degree in Leisure Studies) - Universidade Federal de Minas Gerais, Escola de Educação Física, Fisioterapia e Terapia Ocupacional, 2018.

SOUZA, E. M. A teoria queer e os estudos organizacionais: revisando conceitos sobre identidade. Revista de Administração Contemporânea, v. 21, n. 3, p. 308-326, 2017.

SOUZA, E. M.; COSTA, A. S. M.; LOPES, B. C. Ressocialização, trabalho e resistência: mulheres encarceradas e a produção do sujeito delinquente. Cadernos EBAPE.BR, Rio de Janeiro, v. 17, n. 2, p. 362374, 2019.

SOUZA, E. M.; COSTA, A. S. M.; PEREIRA, S. J. N. A organização (in) corporada: ontologia organizacional, poder e corpo em evidência. Cadernos EBAPE.BR, Rio de Janeiro, v. 13, n. 4, p. 727-742, 2015.

SPARGO, T. Foucault e a teoria queer: seguido de Ágape e êxtase: orientações pós-seculares. Belo Horizonte: Autêntica, 2017.

STASI, M.; EVANS, A. Glitter (foot)ball tactics: negotiating mainstream gender equality in Iceland. Men and Masculinities, v. 16, n. 5, p. 560-578, 2013.

WILLIS, T. Kicking down barriers: gay footballers, challenging stereotypes and changing attitudes in amateur league play. Soccer \& Society, v. 16, n. $2-3$, p. 377-392, 2015.

Gustavo Henrique Carvalho de Castro

ORCID: https://orcid.org/0000-0003-3920-6404

Doctoral student in Administration at the Graduate Program in Administration of the University of Brasilia (UNB), Brasília - DF, Brazil.

E-mail: gustavo.hc.castro@gmail.com

Post-Doctor in Clinical Sociology by Laboratoire de Changement Social - Paris VII; Professor of the Graduate Program in Administration at the University of Brasilia (UNB), Brasília - DF, Brazil. E-mail: marcusvs@unb.br 